\title{
UN DCF와 국제개발협력
}

\author{
윤 지 영 (ODA Watch 정책기획팀장)
}

\section{목 차}

\section{1. 들어가며}

2. UN DCF 논의 경과

3. 2012 UN DCF 전개 과정과 주요 논의 결과

4. $2012 \mathrm{UN} \mathrm{DCF}$ 의 의의 및 평가: 시민사회의 의견을 중심으로 5. 맺으며

\section{1. 들어가며}

지난 7월 5-6일 뉴욕 UN 본부에서 제3차 UN 개발협력포럼(UN Development Cooperation Forum, 이하 DCF)이 열렸다. DCF는 2005년에 열렸던 유엔 정상회의(2005 UN World Summit)에서 개발원조에 대한 개발도상국의 목소리를 반영할 수 있는 지구적 포 럼이 필요하다는 결의를 바탕으로 창설된 포럼이다. 유엔 경제사회이사회(UN Economics and Social Council, 이하 ECOSOC)가 주관하며, 2008년도에 첫 번째 포럼이 개최되었고 2년을 주기로 열리고 있다. $\mathrm{DCF}$ 는 개발도상국, 공여국, 시민사회, 국회, 지방정부, 민간 등 다양하고 포괄적인 범위의 이해관계자들이 모여 개발협력 이슈에 대해 폭넓은 대화가 이루어지는 것을 주요 목표로 두고 있다.

이 글에서는 그간 이루어진 $\mathrm{DCF}$ 논의 과정과 결과를 간략히 살펴보고, 필자가 참여한 제3차 $\mathrm{DCF}$ 회의 결과를 중심으로 $\mathrm{DCF}$ 의 의의를 살펴보고자 한다. 아울러 미래의 개발협력체제 구축 을 위한 DCF의 역할과 함께 이에 대한 한국의 도전과제를 모색해 볼 것이다. 


\section{UN DCF 논의 경과}

\section{(1) 제1차 DCF 결과}

2008년 6월 30일 7월 1일 양일간 열린 제1차 DCF는 UN의 ECOSOC이 국제개발협력의 효 과성과 일관성에 대한 국제적인 대화와 정책적 검토를 위한 주요한 장으로 자리매김하는 것을 목적으로 했다. 논의 결과, 회의에 참여한 다양한 이해관계자들-시민사회, 국회, 지방정부, 민 간 등-은 개발협력이 의미 있는 영향력을 가지기 위해서는 무역, 부채, 투자, 기술, 기후변화, 식량위기 등 다양한 이슈들 간의 상호 보완적인 정책이 매우 중요함을 확인했다. 또한 MDGs를 비롯하여 이미 국제사회가 합의한 원조 공약 이행의 중요성을 재확인하고 예측가능하며 개발 성과를 최대화시킬 수 있는 원조 분배가 보장되어야 함을 강조했다. 그리고 가나 아크라(Accra) 에서 곧 열리게 될 원조효과성에 관한 제3차 고위급회담(Accra High-level Forum on Aid Effectiveness)을 앞두고 원조효과성 이행을 위한 보다 폭넓은 합의가 필요함을 논하기도 했 다. 특히 비구속성 원조, 혁신적 기술지원, 양허성 극대화, 다년도 예측성 증대를 위한 측정 가 능한 목표를 설정해야 함을 주지하며 아크라 회담을 통해 개발 행위자들의 진정한 행동 변화를 요구했다.

마지막으로 $\mathrm{DCF}$ 가 보다 포괄적인 고위급 회담을 지원함으로써 시민사회, 국회, 민간 및 지방 정부를 포함한 모든 이해관계자들의 목소리를 강화하는데 힘쓸 것을 강조하며 2010년에 열릴 2 차 회의에서는 관계자들 간의 합의를 통해 효과적인 개발협력을 이끌어낼 수 있는 보다 포괄적 인 프레임워크(inclusive framework)를 구축하기로 했다.

\section{(2) 제2차 DCF 결과}

제2차 회의는 2010년 9월에 개최될 MDGs에 관한 고위급 총회를 앞두고 2010년 6월 29 30일 이틀간 열렸다. 2 차 회의에서는 1 차 회의에 이어 개발협력의 일관성과 효과성 향상을 위한 구체적인 방안을 논의하는 데에 초점을 두고 특히 MDGs 달성을 위해 개발협력 책무성과 투명성 향상이 중요함을 인지했다. 참가자들은 책무성을 높이기 위해 국회와 시민사회, 지방 정 부의 충분한 참여를 보장해야 하며 원조가 성평등에 미치는 영향 또한 고려해야 함을 확인했다. 또한 지난 2 년간 상호 책무성 향상을 위한 개발 주체들 간의 정치적 의지의 부족과 이에 따른 “상호 책무성 피로현상(mutual accountability fatigue)”을 우려하며 이를 방지하기 위해 국 
가 시스템을 강화하고 모든 행위자에게 적용되는 척도와 명확한 책임을 부여하는 원조 전략을 수립해야 한다고 의견을 모았다.

책무성에 관한 논의 결과 중 더욱 주목할 점은, 국회와 시민사회, 지방정부가 개발협력 활동 책무성 향상을 위한 옹호자이자 동등한 파트너로써 모니터링과 평가 과정에 활발하게 참여할 수 있도록 더 많은 권한을 부여해야 한다고 인지한 점이다. 따라서 국회가 핵심적인 중추 역할 을 다하고 시민사회가 참여할 수 있는 환경을 조성하는 것이 매우 중요하다. 또한 독립적인 회 계 감사 기관, 연구 기관, 미디어들이 관련 정보에 관한 접근성을 허용하고 강화할 수 있도록 체 계적으로 기능하는 것이 요구된다.

2 차 회의는 $\mathrm{DCF}$ 가 개발협력의 트렌드(양과 질, 분배 등) 뿐만 아니라 개발협력 행위자들 간 의 동료 학습을 통해 상호 책무성과 투명성 증진 과정을 정기적으로 점검해나갈 것을 후속 계획 으로 밝혔다. 또한 $\mathrm{DCF}$ 가 국제사회의 정책 대화와 규범을 형성해 나가는 역할을 강화해야 함을 강조하고 있다.

\section{2012 UN DCF 전개 과정과 주요 논의 결과}

\section{가. 준비 과정}

2012년 7월에 열린 제3차 DCF는 개발협력의 환경 변화와 새로운 개발협력 체제 구축을 위한 $\mathrm{DCF}$ 의 역할을 중점으로 Post-2015 논의에 기여하는 것을 목적으로 하고 있다. 이를 위해 2011년 5월부터 8차례의 준비회의를 가지고 급변하는 개발협력 환경 안에서 DCF가 해야 할 역 할을 다지는데 주력했다. 
〈표 1〉 2012 DCF를 위한 8차례 사전준비 회의 개요

\begin{tabular}{|c|c|c|c|}
\hline 차수 & 장소 & 날짜 & 주제 및 주요내용 \\
\hline \multirow[b]{2}{*}{1} & \multirow[b]{2}{*}{ 바마코(말리) } & \multirow[b]{2}{*}{$2011.05 .05 \sim 06$} & $\begin{array}{l}\text { MDG 달성을 향한 개발협력: 효과성과 성과 } \\
\text { Gearing development cooperation towards } \\
\text { the MDGs: effectiveness and Results. }\end{array}$ \\
\hline & & & $\begin{array}{l}\text { 개발협력 활동이 빈곤 감소를 위한 가시적인 성 } \\
\text { 과를 내기 위해서는 원조가 효과적으로 배분, } \\
\text { 전달되고 관리되어야 하며, 그 방식과 목표는 } \\
\text { 다양한 개발 행위자에 따라 다양할 수 있음을 } \\
\text { 강조 } \\
\text { - 그 외에도 파트너국 오너십, 역량 강화, 상호 책 } \\
\text { 무성, 최빈국 지원의 중요성에 대한 논의가 진 } \\
\text { 행 }\end{array}$ \\
\hline \multirow[b]{2}{*}{2} & \multirow[b]{2}{*}{$\begin{array}{c}\text { 이스탄불 } \\
\text { (터키) }\end{array}$} & \multirow[b]{2}{*}{ 2011.05.12 } & $\begin{array}{l}\text { 최빈 개도국을 위한 상호 책무성: } \\
\text { 원조의 질 향상과 그 이상을 위한 프레임워크 } \\
\text { Mutual Accountability for LDC: } \\
\text { A framework for aid quality and beyond }\end{array}$ \\
\hline & & & $\begin{array}{l}\text { - 원조 고아(aid orphans)의 대부분이 최빈국임 } \\
\text { 을 지적하며 공여국과 국제기구들이 최빈국에 } \\
\text { 대해 서로 간의 조율(coordination)을 통한 지 } \\
\text { 원을 확대해야 함을 강조 } \\
\text { - 최빈국의 경우 인적 자원과 제도적 기반이 부 } \\
\text { 족하고 시민사회의 역량이 취약하므로 국내 책 } \\
\text { 무성과 상호책무성의 실현이 어려운 실정임. 의 } \\
\text { 회의 감시 기능과 시민사회의 강화의 중요성 } \\
\text { 제시 }\end{array}$ \\
\hline \multirow[b]{2}{*}{3} & \multirow[b]{2}{*}{$\begin{array}{c}\text { 룩셈부르크 } \\
\text { (룩셈부르크) }\end{array}$} & \multirow[b]{2}{*}{ 2011.10.18 19 } & $\begin{array}{l}\text { 원조의 영향력을 높이기 위한 협력 } \\
\text { Working together to increase } \\
\text { the development impact of aid }\end{array}$ \\
\hline & & & $\begin{array}{l}\text { - 개발도상국의 국내 세입(tax revenue)은 } \\
\text { 물론이고 소액금융과 외국인 직접투자 등 } \\
\text { 다양한 개발 재원을 활용하는 방식으로 원 } \\
\text { 조가 활용되어야 원조의 개발과 빈곤 감소 } \\
\text { 에 대한 영향력이 극대화 될 수 있음을 강 } \\
\text { 조 } \\
\text { 개발도상국이 다양한 개발 재원과 협력의 ㅎㅕㅕㅌㅐ } \\
\text { 들을 효과ㅈㅓㅓ으로 일관성 있게 관리할 수 있는 } \\
\text { 역량을 갖춰야 함 }\end{array}$ \\
\hline
\end{tabular}




\begin{tabular}{|c|c|c|c|}
\hline 차수 & 장소 & 날짜 & 주제 및 주요내용 \\
\hline \multirow[b]{2}{*}{4} & \multirow[b]{2}{*}{$\begin{array}{c}\text { 부산 } \\
\text { (대한민국) }\end{array}$} & \multirow[b]{2}{*}{ 2011.11.29 } & $\begin{array}{l}\text { 개발에 대한 재고찰: } \\
\text { 새로운 지속가능한 개발협력 체계를 향하여 } \\
\text { Rethinking Development: } \\
\text { Towards a New Sustainable Development } \\
\text { Architecture. }\end{array}$ \\
\hline & & & $\begin{array}{l}\text { 원조효과성 원칙이 지속가능한 발전의 개념과 } \\
\text { 맥락에 적절히 부합하는지 검토, 지속가능한 발 } \\
\text { 전이 기존의 개발도상국의 오너십과 리더십 강 } \\
\text { 화 및 공여국 간의 조율 노력을 약화시키지 않 } \\
\text { 는 방안 논의 } \\
\text { - 지속가능한 발전의 우선과제 선정과 정책 입안, } \\
\text { 비용분담에 대한 회원국 간의 상이한 입장 차이 } \\
\text { 인지, 녹색경제를 통한 지속가능한 발전의 달성 } \\
\text { 제안 }\end{array}$ \\
\hline \multirow[b]{2}{*}{5} & \multirow[b]{2}{*}{ 뉴욕(미국) } & \multirow[b]{2}{*}{ 2012.02.09 } & $\begin{array}{l}\text { 개발을 둘러싼 환경의 변화: 협력과 글로벌 파트 } \\
\text { 너십의 의미 } \\
\text { The changing Context of Development: } \\
\text { What does it mean for Cooperation and } \\
\text { Global Partnership }\end{array}$ \\
\hline & & & $\begin{array}{l}\text { - 새롭게 부상하는 다양한 개발 행위자들과 차별 } \\
\text { 화된 접근방식 및 재원 도입이 새로운 기회로 } \\
\text { 작용할 수 있음. 개발도상국들이 이러한 다양한 } \\
\text { 행위자들을 조정할 수 있는 역량을 갖추어야 함 } \\
\text { - 부산 글로벌 파트너십의 이행을 위한 DCF의 } \\
\text { 역할 논의, 개발행위자들의 활동을 조정할 수 } \\
\text { 있도록 DCF의 권한을 강화해야 할 필요성 언 } \\
\text { 급 }\end{array}$ \\
\hline \multirow{2}{*}{6} & \multirow{2}{*}{ 뉴욕(미국) } & \multirow{2}{*}{ 2012.02.27 } & $\begin{array}{l}\text { 개발협력 분야의 민간 자선 단체: } \\
\text { 새로운 기회와 도전 } \\
\text { Private philanthropic organizations in } \\
\text { international development cooperation: } \\
\text { New opportunities and specific challenges }\end{array}$ \\
\hline & & & $\begin{array}{l}\text { - 최근 급부상하고 있는 민간 자선 기관들의 개발 } \\
\text { 협력 홯동 참여 현황 파악, 전통적인 행위자들 } \\
\text { 과의 협력 방안 모색 } \\
\text { - 새로운 개발협력 의제 형성에 민간 자선기관들 } \\
\text { 이 기여할 수 있는 방안 논의 }\end{array}$ \\
\hline
\end{tabular}




\begin{tabular}{|c|c|c|c|}
\hline 차수 & 장소 & 날짜 & 주제 및 주요내용 \\
\hline \multirow[t]{2}{*}{7} & \multirow{2}{*}{$\begin{array}{l}\text { 브리즈번 } \\
\text { (호주) }\end{array}$} & \multirow[t]{2}{*}{$2012.05 .14 \sim 15$} & $\begin{array}{l}\text { 지속가능한 미래 구축: 개발협력의 다양한 파트너 } \\
\text { Shaping a sustainable Future: Partners in } \\
\text { Development Cooperation }\end{array}$ \\
\hline & & & $\begin{array}{l}\text { - 지속가능한 발전을 이루기 위해 개발협력이 나 } \\
\text { 아가야 할 방향과 역할에 대한 논의 }\end{array}$ \\
\hline \multirow{2}{*}{8} & \multirow{2}{*}{$\begin{array}{l}\text { 리우데자네이루 } \\
\quad \text { (브라질) }\end{array}$} & \multirow{2}{*}{ 2012.06.21 } & $\begin{array}{l}\text { 우리가 원하는 미래: 우리가 원하는 미래로 가기 } \\
\text { 위한 개발협력의 역할 } \\
\text { The future we want: The role of } \\
\text { Development Cooperation in Getting us } \\
\text { there }\end{array}$ \\
\hline & & & $\begin{array}{l}\text { - 각 개별국가들이 기존의 개발협력 담론에서 지 } \\
\text { 속가능한 발전 담론으로 전환하는 것을 돕는 방 } \\
\text { 안 논의 } \\
\text { - 개별국가가 가진 개발협력 관련 정책결정 과정 } \\
\text { 과 제도적 메커니즘에 지속가능한 발전에 대한 } \\
\text { 담론의 적용 방안 모색 }\end{array}$ \\
\hline
\end{tabular}

출처 : 저자작성

(1) 제1차 준비회의: 2011 Mali High-level symposium on "Gearing development cooperation towards the MDGs: Effectiveness and Results"

2012년 DCF의 첫 준비회의인 말리 고위급 심포지엄은 국제적으로 경제적인 불안정이 지속 되고 있는 가운데 많은 공여자들이 약속한 원조를 감축하면서 MDGs 달성이 제대로 이루어지 지 않고 있음을 지적하고 있다. 지속가능한 성과는 개발도상국의 리더십을 우선으로, 공여국과 개발도상국 간의 상호책무성이 전제되어 있을 때 획득할 수 있는 것이므로 양자 모두 원조의 성 과에 대한 책무성을 가져야 함을 강조하고 있다. 이에 따라 개발협력 활동이 빈곤 감소를 위한 가시적인 성과를 내기 위해서는 원조의 효과적인 배분과 전달, 관리가 매우 중요하며 그 방식과 목표는 다양한 개발 행위자에 따라 다양할 수 있음을 확인하고 있다. ${ }^{1)}$

1) UN ECOSOC(2011.6.30) Preparing for the 2012 Development Cooperation Forum. Report of the Mali High-level Symposium "Gearing development cooperation towards the MDGs: Effectiveness and results" 
(2) 제2차 준비회의: Special Event at the Fourth United Nations Conference on Least Developed Countries(LDC-IV), "Mutual accountability for LDCs: A framework for aid quality and beyond"

터키 이스탄불에서 열린 제4차 유엔최빈국회의(4th UN Conference on Least Developed Countries) 기간 중 $2012 \mathrm{DCF}$ 의 2차 사전준비회의가 열렸다. 유엔최빈국회의는 지난 1970 년 대 이후 선진국과 저개발국간의 빈부격차가 심화되는 이른바 '남북문제' 가 세계질서에 새로운 위험 요소로 등장하면서 최빈국의 개발문제를 논의하기 위해 1981년부터 10년마다 개최되고 있 다. 최빈국 개발지원을 위한 비전과 이행계획을 제시하는 것을 목표로 약 5 일 동안 정부 간 회 의, 주제별 고위급 회의, 민간 주도 회의, 부대 행사가 열린 가운데 $\mathrm{DCF}$ 를 준비하기 위한 논의 도 이루어진 것이다. 본 사전회의 또한 최빈국에 중점을 두고 최빈국과 공여자 간의 상호 책무 성이 국제적 공약의 이행에 기여할 수 있는 방안에 대해 집중적으로 논의했다. 1 차 회의 결과를 바탕으로, 새로운 프레임워크를 제안하기 보다는 현존하는 프레임을 최빈국에 적용할 수 있는 방안을 모색하는 데 초점을 두었다. 최빈국의 관점에서 원조의 질과 효과성이 무엇인지, 기존의 프레임들이 최빈국과 공여국 간의 상호 책무성을 보장하는데 도움이 되는지, 공여자들이 최빈 국의 수요를 충분히 반영하고 있는지 여부를 살펴보며 향후 공여자와 최빈국 간의 더욱 심도 있 는 정책 대화가 요구됨을 강조했다. 또한 인적 자원과 제도적 기반이 부족하고 시민사회의 역량 이 취약한 점을 고려하여 이러한 점들을 개선할 수 있는 지원의 중요성도 논의되었다. ${ }^{2)}$

(3) 제3차 준비회의: 2011 Luxembourg High-level Symposium on "Working together to increase the development impact of aid"

1차 준비회의에 이어 $2012 \mathrm{DCF}$ 준비를 위한 두 번째 고위급 심포지엄이 룩셈부르크에서 열 렸다. 본 회의는 개발도상국들이 원조의 영향력을 극대화할 수 있도록 돕는 최선의 방법을 모색 하는 것을 목표했다. 논의 결과 개발도상국의 국내 세입은 물론이고 소액금융, 외국인 직접투자 등 다양한 개발 재원을 활용하는 방식으로 원조가 활용되어야 원조의 개발과 빈곤 감소에 대한 영향력이 극대화 될 수 있음을 확인했다. 따라서 장기적으로 원조의 질적 향상과 양적 확대뿐만 이 아니라 원조에 대한 독립성을 강화할 수 있는 정책을 마련하는 것이 중요하다. 개발도상국은 공여국이 제공하는 다양한 형태의 원조와 국내 및 해외의 개발 재원들을 효과적으로 일관성 있

2) UN ECOSOC(2011.5.12) Mutual Accountability for Least Developed Countries: A Framework for Aid Quality and Beyond, "Key messages and recommendations" 
게 운용할 수 있는 역량을 갖춰야 한다.

이에 대해 최빈국들은 최빈국에 대한 원조는 반드시 해외직접투자와 기타 개발 재원을 동원하 는 것을 최우선순위로 지원하여 경제적 성장을 강화하는 방향으로 이루어져야 한다고 강조하였 다. 반면 일부 $\mathrm{NGO}$ 들은 원조가 보건, 교육과 같은 사회적 발전을 지원하는데 쓰였을 때 영향이 극대화되었음을 주장하여 대조된 양상을 보였다. 오랜 논의 끝에, 개발도상국들이 스스로 원조 자원의 배치를 결정할 수 있어야 한다는 점을 강조하며 회의가 마무리 되었다. ${ }^{3)}$

(4) 제4차 준비회의: DCF Advisory Group Special Event on "Rethinking Development: Towards a New Sustainable Development Architecture”

제4차 원조효과성에 관한 고위급회담인 부산 세계개발원조총회 기간 동안 $\mathrm{DCF}$ 의 자문단은 '개발에 대한 재고찰: 새로운 지속가능한 개발협력 체계를 향하여' 라는 주제로 부대 행사를 열 어 $2012 \mathrm{DCF}$ 를 위한 제4차 준비회의를 가졌다. 2012년 6월 브라질 리우에서 열릴 유엔지속가 능발전회의(Rio+20)를 앞두고 지속가능한 발전과 개발협력의 관계에 대한 논의를 본격적으로 시작한 것이다. 본 회의에서는 개발협력이 MDGs 달성을 위해 지속적으로 노력함과 동시에 지 속가능한 개발 의제를 형성하는 데 있어 가장 우선적으로 취해야 할 행동이 무엇인가에 대한 고 민을 중점적으로 다루었다. 이러한 맥락에서 원조효과성 원칙이 지속가능한 발전의 개념과 맥 락에 적절히 부합하는지를 검토하고 지속가능한 발전이 기존의 개발도상국의 주인의식과 리더 십 강화 및 공여국 간의 조율 노력을 약화시키지 않는 방안을 논의했다. 그 결과 지속가능한 발 전의 우선 과제 선정과 정책의 입안, 비용분담에 대한 회원국 간의 상이한 입장 차이를 인지하 고 이에 대한 대안으로 녹색경제를 통한 지속가능한 발전의 달성을 제안했다. 또한 녹색경제는 환경보존과 사회발전, 인간개발을 이루기 위해 필수적인 요소임을 역설하며 녹색경제에 대한 국제적인 논의를 진전시켜나감에 있어 각 국가들의 특수한 상황을 이해하고 정책 결정을 위한 폭넓은 상호의사 교환 및 다각적인 협력이 이루어져야 함을 강조했다. 마지막으로 이러한 협력 을 위한 담론 형성에 $\mathrm{DCF}$ 가 기여할 것을 명시하게 된다. ${ }^{4)}$

3) UN ECOSOC(2011.10.18-19) Preparing for the 2012 Development Cooperation Forum. Report of the Luxembourg High-level Symposium. "Working together to increase the development impact of aid"

4) UN ECOSOC(2011.11.29) Summary of the Special High-Level Event of the DCF Advisory Group at the Forth High Level Forum on Aid Effectiveness on "Rethinking development: towards a new sustainable development architecture" 
(5) 제5차 준비회의: "The Changing Context of Development: What does it mean for cooperation and Global Partnership"

제5차 준비회의는 변화하고 있는 개발협력 환경 안에서의 새로운 글로벌 파트너십을 어떻게 형성해야 하는지에 대한 논의를 중점적으로 다루었다. 새롭게 부상하는 다양한 행위자들의 역 할과 원조 형태에 대해 기존과는 다른 접근법이 요구되고 있음을 인지하고 향후의 개발협력 추 진 체계의 정립 방향을 모색하였다. 그 결과 개발행위자의 다양화는 차별화된 접근방식과 재원 을 도입할 수 있다는 점에서 새로운 기회임에 분명하지만, 개발도상국들이 다양한 행위자들을 조정할 수 있는 역량을 갖추는 것이 새로운 도전 과제임을 확인했다.

또한 부산 세계개발원조총회의 결과로 탄생한 부산 글로벌 파트너십의 이행을 위해 DCF가 해야 할 역할에 대해 논의하여 DCF가 개발협력의 미래를 위한 파트너십 형성에 기여해야함을 강조했다. ${ }^{5)}$

(6) 제6차 준비회의: "Private philanthropic organizations in international development cooperation: New Opportunities and specific challenges"

제 5 차 준비회의가 막을 내린지 얼마 지나지 않아 민간 자선기관들의 활동이 개발협력에 미치 는 영향에 대한 특별 정책 대화를 마련하여 $2012 \mathrm{DCF}$ 의 제6차 준비회의로 논의를 이어나갔다. 5 차 회의에서 언급한 다양한 행위자들 중에서 최근 급부상하고 있는 민간 자선기관들의 기여 현황을 살펴보고 전통적인 행위자들과의 협력 방안을 모색하는 것이 주된 내용이었다. 2010년 에 열린 MDGs 정상회의에서 이미 주지한 바와 같이 MDGs 달성을 위해 이들의 역할과 참여를 확대하는 것이 요구된다는 것을 다시 한 번 확인한 셈이다. 특히 Rio+20의 지속가능한 발전 담 론과 Post-MDGs와 같은 새로운 개발협력 의제 형성에 민간 자선기관들이 기여할 수 있는 방 안이 중점 주제로 다루어졌다.6) 1 일간의 정책대화이니 만큼 민간 자선기관들의 참여가 가져올 다양한 현상에 대해 심도 있는 검토는 이루어지지 않았으나 본 회의의 주요 결과가 $2012 \mathrm{DCF}$ 의 사무총장보고서에 반영된다는 점에서 $\mathrm{DCF}$ 가 민간 자선 기관들의 참여를 주의 깊게 조명하 고 있음을 알 수 있다.

5) UN ECOSOC(2012.1.24) Draft Concept Note. ECOSOC meeting on The Changing Context of Development: What does it mean for Cooperation and Global Partnership

6) UN ECOSOC(2012.02.27) Private Philanthropic Organizations in International Development Cooperation: New Opportunities and Specific Challenges, Key message and Recommendations. 
(7) 제7차 준비회의: 2012 Australia High-level Symposium on "Shaping a Sustainable Future - Partners in Development Cooperation”

Rio+20 정상회의를 한 달쯤 앞두고 열린 제7차 준비회의는 말리, 룩셈부르크에 이어 2012 $\mathrm{DCF}$ 준비를 위한 세 번째 고위급 심포지엄으로써, 부산에서 열린 4차 회의의 연장선상에서 지 속가능한 발전을 이루기 위해 개발협력이 노력해야 할 사항들에 대한 논의를 가졌다. 본 회의에 서는 글로벌 지속가능성에 관한 UN 고위급 패널회담(The UN High-Level Panel on Global Sustainability)가 주지한 바와 같이 현재의 글로벌 개발 모델이 지속가능하지 않음을 인식하 였다. 이에 개발협력이 지속가능한 발전을 위한 세 가지 핵심 축인 경제적, 사회적, 환경적 발전 을 위한 정책 수립에 핵심적인 역할을 해야 함을 역설하였다. 이에 DCF의 논의 결과가 Rio+20 정상회의와 향후 2015 년 이후의 UN이 형성해나갈 개발 의제 논의에 반영될 것임을 밝히고 있 다. 회의 결과 지속가능한 발전을 이루기 위해 개발협력이 나아가야 할 방향과 역할은 다음과 같다. 7)

첫째, 기후변화, 물 부족 및 식량위기에 직면한 취약한 지역사회에 대해 인도주의적 지원을 계속 해야 한다.

둘째, 경제성장을 위해 필수적인 에너지 접근성의 확대에 기여해야 한다.

셋째, 경제활동에 참여하는 개발 행위자들의 역량 개발과 참여 확대에 기여해야 한다.

넷째, 글로벌 경제 시스템에 적응할 수 있도록 신흥 산업의 육성을 위한 정책개발을 지원해야 한다.

다섯째, 공공지출 시스템을 통해 친환경산업을 장려하는 방식으로 경제체제의 전환을 지원해야 한다.

여섯째, 민관협력과 같은 방식의 개발재원의 다각화를 촉진해야 한다.

일곱째, 개발원조의 효율적 전달을 위한 창의적 메커니즘을 확립해야 한다.

여덟째, 개발협력의 투명성을 제공해야 한다.

(8) 제8차 준비회의: DCF Side Event at Rio+20 Conference on "The Future we want: The role of Development Cooperation in Getting Us There"

마침내 $2012 \mathrm{DCF}$ 를 위한 마지막 준비회의가 브라질 리우에서 열린 유엔지속가능발전 회의 의 부대행사로 마련되었다. 본 회의는 지금까지 이어져 온 준비회의에서 논의된 결과를 종합적 으로 정리하여, 각 개별국가들이 기존의 개발협력 담론을 지속가능한 발전으로 전환하는 것을

7) UN ECOSOC(2012.05.15) Preparing for the 2012 Development Cooperation Forum. Report of the Australia High-level Symposium, "Shaping a sustainable future-Partners in development cooperation" 
지원하는 방안에 대해 논의했다. 보다 구체적으로 개별국가가 가진 개발협력 관련 정책결정 과 정 및 제도적 메커니즘에 지속가능한 발전에 대한 담론이 통합적으로 적용될 수 있는 방안을 상 호 경험 공유를 통해 모색했다. ${ }^{8)}$ 본 회의에서 이루어진 논의는 $2012 \mathrm{DCF}$ 회의로 이어져 Rio+20 결과 이행 방안을 구상하는 것으로 연결하게 된다.

\section{나. 2012 UN DCF 주요 결과}

\section{1) 주요 의제와 사무총장 보고서 핵심 요지}

지금까지 살펴본 것처럼, 2012 년 UN DCF는 최근 급변하고 있는 개발협력 환경과 새로운 개 발협력 체제 구축을 위한 주요 사안에 대해 다양한 행위자들이 참여하여 논의할 수 있도록 8차 례의 준비회의를 거쳐 노력해왔다. 2012년 7월 5일 6일 양일간 열린 본 회의는 이러한 내용들 을 기반으로, $\mathrm{DCF}$ 가 개발협력을 통한 지속가능한 발전을 달성하고, 포괄적 파트너십을 구축하 여 개발성과를 증진하며, 다양한 행위자들 간의 상호 책무성을 강화하여 미래의 개발협력 주요 의제에 기여하기 위해 개최되었다.

본 회의 프로그램은 2012년 DCF를 위한 사무총장 보고서 내용을 중심으로 주요 의제별 다양 한 정책대화, 워크숍, 부대행사 등으로 이루어졌다. 주요 의제는 아래와 같이 크게 9 가지의 주 제로 분류된다.

\section{〈Box 1〉 2012 DCF 주요 의제}
(1) 변화의 동력: 개발협력의 미래
(2) 개발협력의 분배: 전략, 책임성, 효과성 제고
(3) 기타 개발재원 동원
(4) 상호 책무성 및 투명성의 중요성
(5) 남남협력과 삼각협력의 증진
(6) 민간 자선 기관 및 지방 정부의 역할 증대
(7) 지속가능한 발전을 위한 개발협력
(8) 개발협력의 미래를 위한 파트너십
(9) DCF의 역할과 후속 논의

8) Jonathan Glennie(2012.05) From Poverty Eradication to Sustainable Development: The implications of an evolving framework for development cooperation. 
주제별 논의 결과를 살펴보기 전에 본 회의를 위해 작성된 사무총장 보고서의 주요 결과를 살 펴보기로 하겠다. 본 보고서는 "국제개발협력의 트렌드와 진전(Trends and Progress in international development cooperation)”이라는 제목으로 8가지의 주요 내용을 담고 있다.

첫째, MDGs의 8번 목표 달성이 제대로 이루어지지 않고 있는 현실을 직시해야 한다.

둘째, 개발을 위한 국내 재원의 동원이 보다 효과적으로 촉진되어야 한다.

셋째, 지속가능한 발전을 증진하기 위한 노력이 보다 강화되어야 한다.

넷째, 개발협력 분배의 질이 훨씬 더 향상되어야 한다.

다섯째, 개발협력의 질과 성과를 위한 노력이 증진되어야 한다.

여섯째, 책무성과 투명성 증진을 위한 폭넓은 노력이 요구된다.

일곱째, 남남협력과 삼각협력의 효과를 최대화해야 한다.

여덟째, 개발협력의 미래 구상에 있어 DCF가 핵심적인 역할을 해야 한다.

위의 8가지 메시지를 기본으로, 보고서는 공여국들이 ODA/GNI 비율을 0.7\%까지 높이겠다 고 국제사회에 명시한 공약을 이행하는데 더욱 박차를 가할 것을 요구하고 있으며 더불어 $\mathrm{MDG}_{\mathrm{s}}$ 달성을 가속화할 것을 주문하고 있다. 개발재원의 확대를 위해 ODA 뿐만 아니라 기타 개발재원을 조달하는 것이 중요하며, 이를 위해 개발협력이 촉매제 역할을 강화해야 함을 강조 한다. 또한 개발협력의 효과성과 상호책무성, 투명성 강화 노력의 중요성과 시민사회, 민간 분 야, 지방자치단체 등의 참여가 확대되어야 함을 제시하고 있다. 특히 원조효과성 제고를 위해 수원국, 공여국 및 기타 행위자들의 역량개발을 위한 지원이 적극적으로 이루어져야 함을 강조 하고 있다.

전통적인 원조 흐름인 남북협력과 새롭게 대두되고 있는 남남 및 삼각협력 간의 상호보완성이 극대화되어야 한다는 점도 보고서가 주요하게 다루고 있는 부분이다. 보고서는 남남협력을 비 용 대비 효과성이 높은 것으로 평가하고 있으며 따라서 동료 학습이 가능한 남남협력의 상대적 이익을 충분히 활용해야 할 것을 강조하고 있다. 마지막으로 원조가 아닌 다른 분야의 이슈들과 일관성을 가지기 위한 강력한 조정의 필요성과 함께 새로운 개발협력체제에 대한 논의 과정에 $\mathrm{DCF}$ 가 기여해야 함을 강조하고 있다.

\section{2) 주제별 논의 결과}

(1) 변화의 동력: 개발협력의 미래 
동 주제 관련 논의에서는 개발협력의 미래를 위한 강력한 노력이 필요하다는 주장이 강조되었 다. 주요 내용으로는 2002년의 몬터레이 선언을 지키기 위한 강력한 행동으로 시장 접근성 강 화, 무역 촉진, 기술 전수, 불법 자금 유출 퇴치 등이 강조되었고 이에 대해 개발도상국과의 광 업 계약의 재협상, 금융거래 과세(Currency Transaction Levee) 등이 현실적인 대안이 될 수 있다는 주장도 제기되었다.

참가자들은 개발원조가 빈곤과 기아 퇴치, MDGs 달성을 위한 주요한 동력임을 다시금 확인 하고 개발효과성을 이루기 위해 효과성을 측정할 수 있는 능력의 배양이 동시에 이루어져야 함 을 지적하였다. 특히 $\mathrm{OECD}$ 와 같은 선진 공여국들이 아닌 개발도상국이 스스로 개발 수요를 발 굴하고 원조효과성을 평가할 수 있어야 한다는 점이 강조되었다.

또한 대부분의 국가들이 개발협력의 환경 변화에 따른 다수의 이해관계자들 간의 일관성과 조 정의 필요성이 시급함을 역설하였다. 개발도상국들은 급변하고 있는 환경 안에서 새로운 형태 의 개발협력 활동이 이루어지고 있음에도 불구하고 $\mathrm{ODA}$ 의 중요성을 간과해서는 안 됨을 강조 하며 남남협력은 기존의 ODA를 대체하는 것이 아닌 보완하는 역할을 해야 함을 주장했다. 또 한 일부 개발도상국들은 개발협력의 미래를 구상할 때 취약국들에 대한 고려가 더욱 필요함을 강조했다.

(2) 개발협력의 분배: 전략, 책임성, 효과성 제고

개발협력은 최빈국, 분쟁국 및 취약국과 같이 가장 지원이 필요한 곳에 우선적으로 분배되어 야 한다는 점과 개발도상국의 우선순위에 맞는 지원의 중요성이 재차 언급되었다. 이러한 맥락 에서 직접예산지원(Budget support)과 같은 원조 모달리티 적용의 강화와 개발도상국의 역량 개발이 중요하다는 의견이 나왔다. 또한 조건부 원조를 줄이고 원조예측성과 유연성을 향상해 야 한다는 주장이 제기되었다. $\mathrm{ODA}$ 의 분배 기준으로는 개발도상국의 경제적 지위 고려 여부가 언급되었으며, 원조배분이 정치적 과정이자 수원국의 필요와 원조 흡수 능력 등을 종합적으로 고려하여 이루어져야 함을 강조했다. 개발도상국들은 동 주제에 대해 글로벌 차원의 일관성과 무역 및 시장접근에 대한 지원, 개발역량과 기술이전에 대한 투자 등을 요청했다.

(3) 기타 개발재원 동원

$\mathrm{ODA}$ 의 예측가능성과 최빈개도국에 대한 집중이 강조되면서 $\mathrm{ODA}$ 가 광범위한 개발의 촉매제 로써 교육, 보건, 인프라 관련 서비스의 제공에 기여하고 있다는 의견이 제시되었다. 특히 공여 국들과 IMF는 ODA 뿐만이 아니라 개발도상국 내의 다양한 개발재원을 동원할 수 있는 방안으 
로 제도 개선과 거버넌스 구축을 시급히 모색하는 것이 필요하다는 주장과 함께 그 예로 포괄적 인 재정 시스템 구축을 통한 세입 및 국민 저축 증가, 조세징수 분야의 개혁의 필요성을 강조했 다. 이에 대해 시민사회에서는 개발도상국에서 선진국으로의 재원 이전이 매우 높으며 2011년 한해 8.270억불이 선진국의 채권구입을 위해 사용되었음을 지적하기도 했다. 시민사회는 국내 재원의 중요성과 함께 재원활용을 위한 계획과 역량에 대한 지원을 강화하고 구속성 원조를 철 폐할 것을 요구했다.

(4) 상호 책무성 및 투명성의 중요성

국가 수준의 개발성과 증진을 위해 상호 책무성과 투명성이 핵심적임을 재확인했다. 강력한 원조 정책과 성과 평가 프레임워크를 통한 원조 제공자와 수원국 간의 상호 책무성이 증진된 대 표적인 사례로 케냐가 언급되었다. 케냐 정부는 2010년 상호책임성을 강화한 헌법을 도입하여 예산의 투명성이 제고되었음을 밝혔다. 또한 원조를 받는 47여개의 부처와 기관이 공여국과 직 접 협상하게 하여 원조효과성을 제고할 수 있었음을 공유했다.

하지만 동시에 개발 파트너십의 불균형이 점차 커지고 있다는 우려도 제기되어 국가 수준의 진전을 가속화하기 위해 강력한 글로벌, 지역적 수준의 프레임워크가 작동되어야 한다는 주장 이 제시됐다. 이에 개발도상국과 원조 제공국가 모두 정치적 의지와 리더십을 가지고 상호 책무 성을 보장할 수 있는 강력한 제도와 법적 프레임워크를 구축할 것을 요구 받았다.

이어 상호 책무성 강화를 위해 DCF가 사례 교류와 상호 학습을 위한 가장 적합한 플랫폼으로 언급되면서 향후 이에 대한 후속 논의가 이루어질 것을 나타내기도 했다.

(5) 남남협력과 삼각협력의 증진

새로운 개발협력 환경의 주요 변화로 남남협력과 삼각협력의 증진이 재차 강조되었으나 앞서 첫 번째 주제 논의에서도 제기된 바와 같이 남남협력과 삼각협력은 기존의 개발 파트너십을 대 체하는 것이 아니라 보완하는 것으로 이해해야 한다는 주장이 개발도상국들을 중심으로 강조되 었다. 또한 남반구 원조 제공자들의 차별화된 개발 경험이 주는 교훈을 통해 낮은 비용과 적합 한 기술로 개발 성과를 높일 수 있는 방안을 검토하는 것이 요구되었다. 삼각 협력의 경우에는 개발도상국의 역량 개발에 핵심적인 역할을 하고 있다는 평가가 주를 이루었는데, 그 예로 남반 구의 원조 제공자가 원조 조정을 강화하고 자국 정부가 자체적으로 시행하는 평가를 확대하여 개발협력활동을 제공하기 위한 제도를 개선하고 있다는 설명이 따랐다. 남남협력과 삼각협력에 대해서는 향후에도 지속적으로 좋은 사례의 교류를 촉진하여 상호간의 대화와 명확한 분석이 
확대되어야 한다는 주장이 강조되었다.

(6) 민간 자선기관 및 지방 정부의 역할 증대

참가자들은 민간 자선기관들이 혁신적인 접근법을 통해 개발협력 활동에의 참여를 확대하고 있다는 사실에 공감했다. 또한 다소 위험을 감수하면서도 이들의 참여 증진을 위한 제도 개선 등 성과 목표를 가질 필요가 있다는 주장이 제기되었다. 반면 민간 기관들이 참여할 때 도덕성 을 가장 중요한 기준으로 삼아야 한다는 주장도 언급되었다. 지방 정부의 경우 중앙정부보다 지 역사회에 가깝게 다가갈 수 있다는 장점이 언급되며 스페인, 독일, 가나, 우루과이, 에콰도르 등 일부 국가들은 개발협력을 위한 지방자치 단체의 참여 현황과 모범 사례를 공유하기도 했다. 마 지막으로 향후의 새로운 글로벌 파트너십에 있어 정부와 시민사회, 민간이 각자의 비교우위와 장점을 고려하여 긴밀하게 협력하는 것이 중요하다는 점을 인식하고, 이들 행위자들의 영향력 과 성과 및 질에 대한 상세한 분석 또한 요구되었다.

(7) 지속가능한 발전을 위한 개발협력

지속가능한 발전을 위한 개발협력의 역할에 대해서는 앞서 살펴본 사전 준비회의에서도 특별 히 강조된 만큼 본 회의에서도 반복적으로 강조되었다. 다시 말해, 경제적, 사회적, 환경적 지속 가능성을 보장하는 개발협력의 중요성과 이 세 가지 영역 간의 일관성의 중요성, 지속가능발전 목표 달성을 위한 혁신적 재원 마련의 중요성이 주요 내용으로 다루어졌다. 참가자들은 현존하 고 있는 개발협력에 관한 다양한 이니셔티브와 메커니즘 구축에 있어 지속가능한 발전이 최우 선 순위로 고려되어야 한다는 점을 인식하고, 이를 위한 제도적 틀과 거버넌스의 중요성에 합의 했다.

(8) 개발협력의 미래를 위한 파트너십

본 회의의 목적이자 핵심 주제로써 개발협력의 미래를 위한 파트너십 구축 방안을 논의했다. 참가자들은 밀레니엄 선언의 핵심 가치가 2015년 이후에도 지속적으로 유의미할 것이라는 의 견에 동의하며, MDGs의 강점과 힘을 기반으로 하나의 글로벌 개발 의제를 형성하기 위해 협력 할 것을 합의하였다. 또한 지속가능한 발전 담론과 부합하는 방향으로 MDGs 의제를 향상시켜 야 하며 특히 MDGs의 8번 목표인 글로벌 파트너십을 더욱 강화해야 함을 강조했다. 또한 부산 세계개발원조총회의 합의사항 이행을 위한 책임성을 강화하고 효과적인 개발협력을 위한 정치 적 모멘텀을 유지할 것을 상호 독려하였으며, Post 2015 의제를 형성해 나가는 과정에서 부산 글로벌 파트너십과 $\mathrm{DCF}$ 간의 보완적 시너지의 중요성이 언급되었다. 새로운 파트너십에 있어 시민사회와 민간, 국회의 역할에 대한 관심을 가져줄 것을 당부하는 의견도 제시되었다. 
(9) $\mathrm{DCF}$ 의 역할과 후속 논의

회의는 $\mathrm{DCF}$ 의 역할과 차기 회의의 논의 주제를 정리하는 것으로 프로그램을 마무리하였다.

서두에서도 언급했듯이 $\mathrm{DCF}$ 의 가장 큰 특징인 다양한 행위자들을 포괄적으로 포함하는 플랫폼 으로서의 기능을 적극적으로 수행할 것이 강조되었다. 또한 개발협력의 변화하는 환경 속에서 지속가능한 발전과 Post 2015 의제에 맞게 $\mathrm{DCF}$ 의 역할과 기능을 조정하는 방안의 필요성이 차기 회의에서 검토되어야 함을 향후 과제로 제시하였다.

또 다른 논의 과제로는 개발협력이 지속가능한 발전을 향상시키고 장기적으로 원조 의존성을 감소시키기 위해 다른 개발 재원을 효과적으로 촉진하는 방안이 언급되었다. 책무성과 투명성 및 성과 중심의 개발 파트너십의 진전을 위해 $\mathrm{DCF}$ 의 적극적인 역할이 요구된 점도 중요하다. 마지막으로 Post 2015 의제 형성과정에서 $\mathrm{DCF}$ 와 이해 관계자들의 적극적인 참여를 요청하며 제 3 차 $\mathrm{DCF}$ 회의가 막을 내렸다.

\section{2012 UN DCF의 의의 및 평가 : 시민사회의 의견을 중심으로}

이번 회의에 참여한 시민사회단체들은 금번 $\mathrm{DCF}$ 에 대한 시민사회의 평가 의견과 제안을 10 가지 항목으로 정리한 성명서9)를 폐막 선언시 낭독하고 사무국에 제출하였다. 성명서에 따르면 시민사회는 $\boldsymbol{\Lambda}$ 공여국들이 약속한 ODA 규모를 축소시키고 있는 것에 대해 깊은 우려를 표명하 며, $\boldsymbol{\Delta} \mathrm{DCF}$ 가 규범적 및 기술적인 토론과 논쟁을 제공하는 지구적 포럼이자 모든 개발협력의 주체가 동등하게 참여하는 포괄적인 플랫폼임을 재확인하고, $\boldsymbol{\Lambda}$ 국제시민사회가 개발협력에 관 한 지구적 논의 과정에 영향을 미칠 수 있는 공간이 점차 축소되고 있는 상황에서 $\mathrm{DCF}$ 에 시민 사회가 참여할 수 있음을 환영하며, $\boldsymbol{\Delta} \mathrm{DCF}$ 가 UN 산하 기구로서 개발협력의 주요 국제적 기준 (인권, 노동, 반부패, 지속가능한 발전 등에 관한)을 준수할 것을 요구하며, $\mathbf{\Delta} 2014$ 년에 열릴 제4차 $\mathrm{DCF}$ 에서 성평등 및 사회경제적 불평등에 관한 고위급 심포지엄을 개최할 것을 요구하며 A $\mathrm{DCF}$ 가 참여적이고 민주적 원칙에 따라 Rio 20 의 결과 이행과 Post 2015 개발 의제 논의 형성에 중요한 역할을 할 수 있음을 확신하며 $\boldsymbol{\Lambda}$ 정부와 국가가 $\mathrm{DCF}$ 의 향후 행동계획 이행을 위한 재정을 전적으로 지원할 것을 요구하고 있다.

9) The CSO's room statement at the 2012 DCF 
앞서 살펴본 주요 논의 결과와 시민사회의 의견을 통해 금번 DCF가 다양한 개발협력 행위자 들과 Post 2015 를 중심으로 하는 새로운 개발협력체제의 구축을 위한 논의의 기반을 조성했다 는 점에서 그 의의를 찾을 수 있다. 이를 통해 $\mathrm{DCF}$ 의 가장 큰 특징이 개발협력의 주요한 이슈 관련 다양한 논의를 위한 장을 제공하는 포럼으로서 국가뿐만이 아니라 시민사회, 민간, 국회, 지방정부 등 다양한 개발협력 주체들이 워크숍, 정책대화, 부대 행사 등의 여러 형태의 논의에 참여할 수 있다는 점을 재확인할 수 있다.

하지만 참여자들의 합의에 기반을 둔 구속력이 있는 공식 결과문서가 없고 약한 수준의 선언 과 실천 방안만을 제시하고 있어 다양한 행위자들 간 주고받은 의미 있는 많은 대화들을 실질적 으로 이행하거나 강제할 수 있는 메커니즘이 없다는 점은 근본적인 한계로 볼 수 있다. 이러한 점은 향후의 새로운 개발협력 파트너십의 구축에 가지게 될 영향력 면에서 $\mathrm{OECD}$ 와 긴장관계 를 유발할 수도 있을 것이다. 이번 회의에서 일부 개발도상국들이 부산총회의 결과로 탄생한 부 산 글로벌 파트너십의 이행 논의가 여전히 $\mathrm{OECD} \mathrm{DAC}$ 을 중심으로 이루어지고 있는 것으로 간 주하고 있음을 확인했듯이, 향후 Post 2015 개발의제와 Post 부산 의제를 연계하여 일관된 개 발협력 의제를 설정하는 데 있어 $\mathrm{OECD}$ 와 UN 간의 주도권 다툼이 일어날 우려도 예상할 수 있 다.

관련하여 $\mathrm{DCF}$ 를 비롯한 $\mathrm{UN}$ 은 부산 글로벌 파트너십의 운영을 위한 사무국을 $\mathrm{OECD}$ 와 공동 으로 담당하게 된 점을 효과적으로 활용하여 동 파트너십과 Post-MDGs 의제 간의 연계 노력 에 적극적으로 참여해야 할 것이다. UN DCF를 포함한 UN 체제가 최빈국과 개발도상국, 시민 사회와 민간 등 다양한 행위자들에 대한 포괄성을 유지하면서 새로운 개발협력 의제 형성을 주 도해나갈 수 있을 것인가에 대해서 아직은 낙관하기 어렵다. 그럼에도 불구하고 $\mathrm{DCF}$ 는 다양한 행위자들의 목소리를 폭넓게 수렴할 수 있는 특징을 지속적으로 강조하여 살려내어 개발협력의 당사자인 개발도상국의 주인의식과 의견을 적극적으로 담아내어 개발협력의 효과성을 높이는 데 기여해야 할 것이다.

\section{5. 맺으며}

지금까지 살펴본 것처럼 $\mathrm{DCF}$ 는 급변하는 개발협력 환경을 인식하고 새로운 개발협력 체제 구축을 위해 다양한 행위자들의 의견을 수렴하는 역할을 하고 있다. 개발협력 활동 및 정책결정 
과정에 개발도상국의 목소리를 반영하기 위해 창설된 것을 고려하면, 2008년부터 3차례에 걸 쳐 이루어진 논의과정에서 이러한 목표는 어느 정도 이루어지고 있는 것으로 판단된다. 다만 $\mathrm{UN}$ 의 많은 논의들이 실질적인 이행의 강제력을 담보하지 못하고 권고에 그치고 있는 한계를 $\mathrm{DCF}$ 또한 노정하고 있는 것이 사실이다. $2012 \mathrm{DCF}$ 를 위한 사무총장 보고서와 회의 결과에서 도 강조했듯이 DCF가 개발협력의 미래 구상에 있어 핵심적인 역할을 하기 위해서는 이러한 한 계를 극복하기 위한 다각도의 노력이 필요하다. 즉, Post 부산, Post MDGs, 지속가능한 발전 담론 등 다른 국제 담론 및 규범들의 논의 체계와 밀접하게 연계하여 보다 강력한 의제설정의 역할을 강화해야 할 것이다.

한국 정부의 경우 부산 세계개발원조총회의 개최국이자 부산 글로벌 파트너십의 이행을 위한 집행위원회의 공여국 대표로 참여하며 동 파트너십의 적극적인 이행을 통해 국내 ODA 및 개발 협력 추진 체계의 선진화 노력과 연계할 계획을 가지고 있다. 반면 DCF에는 상대적으로 참여가 저조한 편으로 국내의 개발협력 정책과 집행 시스템에 $\mathrm{DCF}$ 의 논의 결과를 반영해온 노력이 부 족하다고 할 수 있다. 하지만 부산 글로벌 파트너십을 중심으로 하는 Post 부산 의제와 MDGs 를 중심으로 하는 Post 2015 의제 및 지속가능한 발전 논의가 상호 유기적으로 연결되어 있으 며, 모두 궁극적으로는 지구촌의 불평등을 줄이고 지속가능한 공존을 목표하고 있음을 인식할 필요가 있다. 따라서 두 논의를 통합적으로 국내에 적용 및 이행할 수 있는 방안을 모색하는 노 력을 지속해나가야 한다. 두 논의 모두 다양한 개발주체의 참여를 바탕으로 공동의 목표 달성을 위한 정치적 의지와 실천적 이행을 요구한다는 점을 인식하고, 이를 바탕으로 새로운 개발협력 의 패러다임 형성에 기여함과 동시에 국내적인 개선 방안과 전략 마련에 힘써야 할 것이다. 


\section{참고문헌}

\section{1. 국내문헌}

ODA Watch 사무국(2012.07). 2012 UN Development Cooperation Forum 회의참석 결과 보고서(내부 문서)

KoFID(2012.07) 국제 Outreach Debriefing 발표자료 “2012 유엔 개발협력 포럼 주요결과와 향후 과제”

\section{2. 국외문헌}

UN ECOSOC(2008) 2008 Development Cooperation Forum. Official summary of the presidendt of the Economic and Social Council

UN ECOSOC(2010.07.06) 2010 Development Cooperation Forum. President's Summary. Development Cooperation Forum 2010

UN ECOSOC(2011.6.30) Preparing for the 2012 Development Cooperation Forum. Report of the Mali High-level Symposium "Gearing development cooperation towards the MDGs: Effectiveness and results"

UN ECOSOC(2011.5.12) Mutual Accountability for Least Developed Countries: A Framework for Aid Quality and Beyond, "Key messages and recommendations"

UN ECOSOC(2011.10.18-19) Preparing for the 2012 Development Cooperation Forum. Report of the Luxembourg High-level Symposium. "Working together to increase the development impact of aid"

UN ECOSOC(2011.11.29) Summary of the Special High-Level Event of the DCF Advisory Group at the Forth High Level Forum on Aid Effectiveness on "Rethinking development: towards a new sustainable development architecture"

UN ECOSOC(2012.1.24) Draft Concept Note. ECOSOC meeting on The Changing Context of Development: What does it mean for Cooperation and Global Partnership

UN ECOSOC(2012.02.27) Private Philanthropic Organizations in International Development Cooperation: New Opportunities and Specific Challenges, Key message and Recommendations. 
UN ECOSOC(2012.05.15) Preparing for the 2012 Development Cooperation Forum. Report of the Australia High-level Symposium, "Shaping a sustainable futurePartners in development cooperation"

UN ECOSOC(2012.06.06) Trends and Progress in international development cooperation. Report of the Secretary-General

UN ECOSOC(2012.07.06) Closing Statement, President of the Economic and Social Council, 2012 United Nations Development Cooperation Forum

Jonathan Glennie(2012.05) From Poverty Eradication to Sustainable Development: The implications of an evolving framework for development cooperation.

The CSO's room statement at the 2012 DCF 